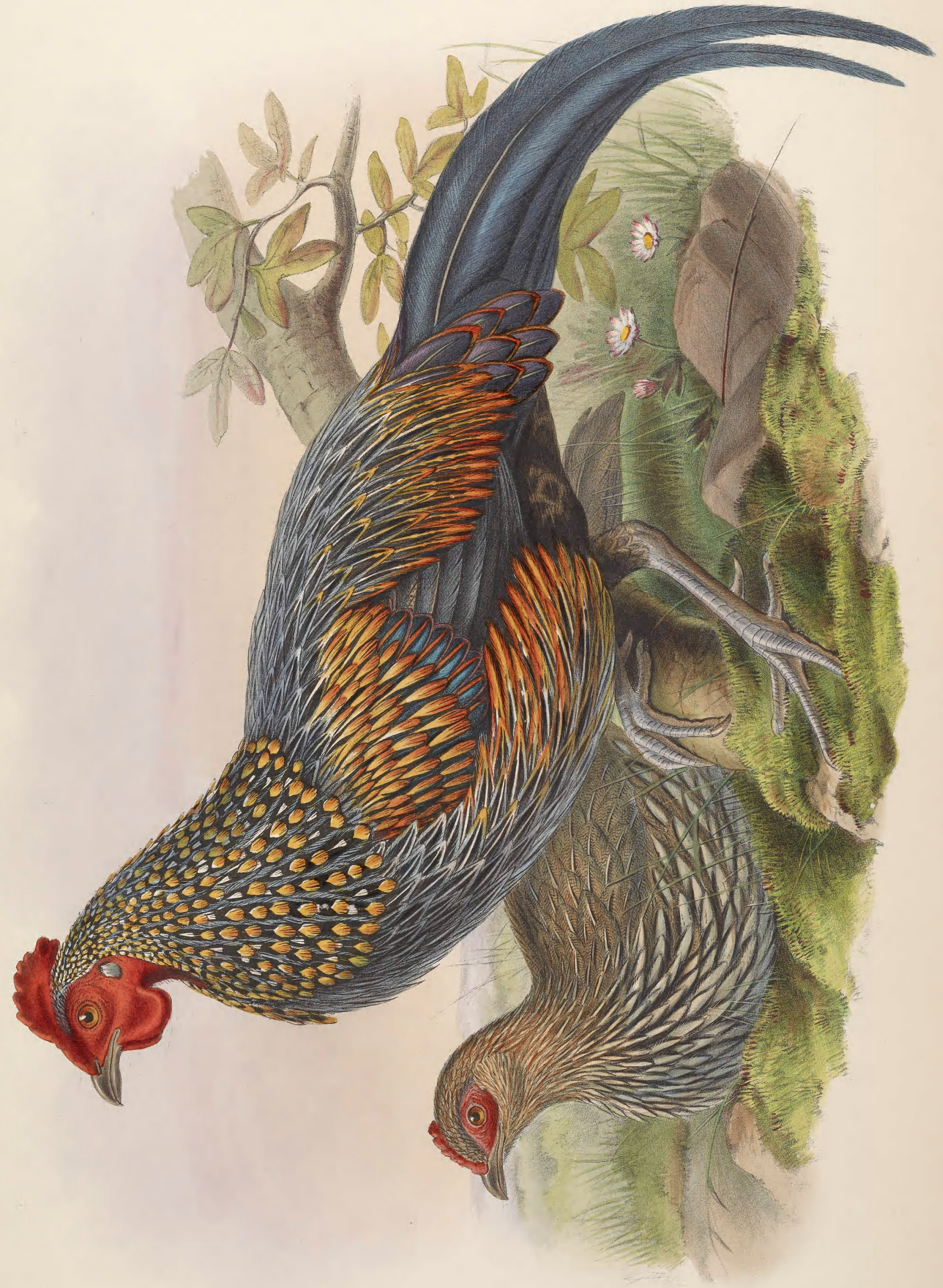




\title{
GALLUS SONNERATI.
}

\author{
(Sonnerat's Jungle-fowl.)
}

Coq sauvage des Indes, Sonn. Voy. Ind. ii. p. 153, pl. xciv. (1782).

Poule sawage des Indes, id. t.c. p. 160, pl. xev. (1782).

Wild Cock, Lath. Gen. Synopsis, ii. pt. ii. p. 698 (1783).

Phasianus gallus, Gm. Syst. Nat. i. p. 737. no. 1 (1788).-Lath. Ind. Orn. ii. p. 625 (1790).

Gallus sonneratii, Temm. Pigeons et Gallin. iii. p. 659 (1815).-Id. Pl. Col. v. pls. 232, 233 (1825)._Gray, Gen. B. iii: p. 499 (1845).-Blyth, Ann. Nat. Hist. xx. p. 389 (1847).-Blyth, Cat. B. Mus. A. S. B. p. 243 (1849).-Burgess, P.Z.S. 1855, p. 29.-Bp. Comptes Rend. 1856, p. 879.-Sacc, Rev. et Mag. de Zool. 1862, p. 11, pl. iii.-Sclater, P. Z. S. 1863, p. 122.-Gray, List Gallinæ Brit. Mus. p. 39 (1863). -Jerd. Birds of India, iii. p. 539 (1864).--Elliot, Monogr. Phasianidæ, ii. pl. xxxiv. (1872).

Phasiamus indicus, Leach, Zool. Misc. ii. p. 6, pl. 61 (1815).

Although this bird has been known to science for so many years, our information respecting it cannot be called extensive; and the notes which Mr. Elliot published in his 'Monograph' still contain nearly the whole of it. I therefore transcribe from his book the following observations :- "This, the handsomest of the Jungle-fowl, is found in the southern part of India; and by the singular spots upon the hackles, as though yellow sealing-wax had been dropped upon them, it is easily distinguished from all the other members of the genus. For a description of its habitat, as well as some interesting remarks on its mode of living, I quote from Jerdon :- 'This handsome Jungle-fowl is found in Southern India only, extending on the east coast to a little north of Godavery, in Central India, to the Pachmarri or Mahadeo hills, north of Nagpore, and on the west coast to the Rajpeehla hills, where it meets the Red Jungle-fowl. Its occurrence on the Pachmarri hills is most probably its eastern extension from the Western Ghâts and the Rajpeehla hills; and it will probably be found all along the Sathpoora range. I do not know of its occurrence east of the Mahadeo hills, till the neighbourhood of the lower part of the Godavery is reached. It is very abundant on the Malabar coast, especially in the more elevated districts, as in the Wynaad, and it ascends to the summit of the Neilgherries; it is also common in suitable localities on the Eastern Ghâts, and in the various ranges in the south of India. It is not rare in the Naggery Hills, near Madras, and is constantly brought for sale to the Madras market.

" "Like Gallus ferrugineus it is particularly partial to bamboo jungles. Early in the morning, throughout the Malabar coast, the Wynaad, \&c., Jungle-fowl may always be found feeding on the roads; and with dogs you are certain of getting several shots on the roadside, the birds perching at once on being put up by dogs. In some districts where they can be beaten out of the woods, and especially on the Neilgherries, very pretty shooting is to be had at this Jungle-cock, the sharply defined woods (or sholas, as they are called) being well adapted to being beaten for game. The hen lays from February to May, generally having from seven to eight eggs of a pinky cream-colour, under a bamboo clump. The call of the cock is very peculiar, being a broken and imperfect kind of crow, quite unlike that of a Red Junglecock, and impossible to describe.'

"Mr. Blanford, in a communication to the Journal of the Asiatic Society upon the geographical distribution of the Red and Sonnerat Jungle-fowls, says:- 'I regret very much having been the means of misleading Dr. Jerdon as to the distribution of the Red Jungle-fowl. I had been told by two different observers that they had seen and shot Jungle-fowl, exactly like the common Barndoor-fowl, in and near the Rajpihla hills; and a third had assured me that he had seen specimens of two different kinds from the same neighbourhood. I have now been through the Rajpihla hills, and the Western Satpooras pretty thoroughly, and I am convinced that the only Jungle-fowl inhabiting those ranges is Gallus sonnerati. This species is also found north of the Nerbudda, in the jungles east of Baroda, around Chota Oodipoor; but how far it extends to the north and north-west I cannot say. It is not improbably to be found in the Aruvelli range, and perhaps Mount Aboo. It occurs throughout the Satpoora hills, north of Kandesh, and, indeed, throughout the Taptee valley. Further south I have recently shot it in the jungles just east of Chanda. Jerdon mentions its occurrence at Pachmurri, where, however, I learn from Lieut. J. Forsyth that $G$. ferrugineus also occurs. Lieut. Forsyth adds that the two kinds of Jungle-fowl meet on the plateau at Pachmurri, and he has shot both there.", 
The following is Mr. Elliot's description of the bird:-

"The male has the back part of the head covered with short black feathers, the shafts white, widening at the ends into a kind of spatule. The hackles are very long, covering the entire neck, black, covered at regular intervals with white spots, and tipped with a yellowish spot, the end of the feather being formed of a singularly brittle substance, resembling a fine shaving in texture. The upper parts are blackish brown, edges of the feathers grey, and the shafts white. The upper tail-coverts like the back, the feathers long and lanceolate in shape, spotted with buff near the end, and margined with chestnut near the tip. Underparts black, shafts of feathers white, and the centres and margins greyish white; some of the flank-feathers have the terminal margins chestnut. Primaries dark brown, as are also the secondaries; a large patch upon the wing, the feathers of which have their centres white, terminating in red, and formed of the same brittle substance as the ends of the hackles, making a very conspicuous and ornamental spot. The comb is small, serrated at the edge, and, together with the naked skin of the face and throat and also the wattles, is red. Upper tail-coverts and tail blue, with green reflections, the two central tail-feathers being very long and curving downwards. The feet and tarsi are flesh-colour; bill horn-colour.

"The female has the top of the head light brown; neck light brown, shafts white, and margins black. Rest of upper surface rufous brown, mottled with black; shafts white. Breast and flanks white, margins of the feathers black. Abdomen white; tail dark brown, mottled near the edges with rufous brown. Small extent of bare skin around the eyes red. Bill yellowish ; feet and tarsi flesh-colour."

The figures are rather under the natural size. 


\section{$2 \mathrm{BHL}$ Biodiversity Heritage Library}

Gould, John. 1877. "Sonnerat's Jungle-fowl, Gallus sonnerati [PI. 56]." The Birds of Asia 7(XXX), -. https://doi.org/10.5962/p.323337.

View This Item Online: https://www.biodiversitylibrary.org/item/122491

DOI: https://doi.org/10.5962/p.323337

Permalink: https://www.biodiversitylibrary.org/partpdf/323337

\section{Holding Institution}

Smithsonian Libraries

\section{Sponsored by}

Smithsonian Institution Libraries

\section{Copyright \& Reuse}

Copyright Status: Not in copyright

This document was created from content at the Biodiversity Heritage Library, the world's largest open access digital library for biodiversity literature and archives. Visit BHL at https://www.biodiversitylibrary.org. 